\title{
KIT NP_000213.1:p.A829P
}

National Cancer Institute

\section{Source}

National Cancer Institute. KIT NP 000213.1:P.A829P. NCI Thesaurus. Code C155710.

A change in the amino acid residue at position 829 in the mast/stem cell growth factor receptor Kit protein where alanine has been replaced by proline. 